\title{
REPUTASI DALAM MENDORONG KEPERCAYAAN DAN MINAT BELI KONSUMEN PRODUK MAKANAN UMKM DI CILEUNGSI
}

\author{
Oleh: \\ Heru Mulyanto'), Rasipan'), Meli Andriyani ${ }^{31}$ \\ drherumulyanto@gmail.com ${ }^{1)}$, rasipanauthor@gmail.com $\left.{ }^{2}\right)$, meli1823@gmail.com $^{3)}$ \\ Sekolah Tinggi Ilmu Ekonomi IPWI Jakarta1,2,3)
}

\begin{abstract}
ABSTRAK
Penelitian ini bertujuan untuk menganalisis reputasi dalam mendorong kepercayaan dan minat beli konsumen produk makanan UMKM di Cileungsi. .

Penelitian dilakukan di Cileungsi Kabupaten Bogor dengan jalan menyebarkan kuesioner konsumen produk makanan UMKM. Konsumen yang dijadikan adalah sebanyak 100 orang dimana pengambilan sampel dilakukan dengan accidental sampling. Data hasil kuesioner dianalisis dengan menggunakan model persamaan structural (Structural Equation Modelling).

Reputasi mempengaruhi minat beli konsumen produk makanan UMKM secara langsung maupun tidak langsung melalui kepercayaan yaitu reputasi meningkatkan kepercayaan dan mendorong minat beli konsumen: 1) Reputasi berpengaruh terhadap kepercayaan dengan arah positif; 2) Kepercayaan berpengaruh terhadap minat beli konsumen UMKM makanan dengan arah positif; 3) Reputasi berpengaruh terhadap minat beli konsumen UMKM makanan dengan arah positif
\end{abstract}

Kata Kunci: Reputasi, Kepercayaan, Minat Beli

\section{PENDAHULUAN}

Minat beli merupakan awal dari terbentuknya keputusan pembelian (Maghfiroh, Arifin, \& Sunarti, 2016) yang pada akhirnya dapat mendatangkan pembelian yang sesungguhnya. Kurangnya minat beli konsumen merupakan permasalahan bagi produsen atau pelaku usaha. Permasalahan ini di dialami oleh pelaku UMKM makanan di Cileungsi. Konsumen lebih percaya pada restoran yang sudah memiliki nama besar atau dikenal. Hal ini memberikan arti bahwa minat beli merupakan hal yang penting dalam rangka mendatangkan pembelian sesungguhnya.

Begitu pentingnya minat beli konsumen bagi perusahaan tergambar dari banyaknya bahasan mengenai minat beli. Bahasan minat beli dilakukan pada konsumen dan produk yang berbedabeda diantaranya pengguna youtube (Yuniyanto \& Sirine, 2018), konsumen toko online (Shahnaz \& Wahyono, 2016) produk makanan minuman (Meilani \& Simanjuntak, 2012), mahasiswa (Ambarwati, Sunarti, \& Mawardi, 2015) dan lain-lain.

Minat beli tidak muncul begitu saja tetapi perlu dibangkitkan. Inilah yang perlu di lakukan UMKM makanan di Cileungsi. Ada berbagai cara yang dapat digunakan untuk mendorong minat beli misalnya melalui iklan yang lebih menarik (Yuniyanto \& Sirine, 2018), meningkatkan citra merek yang lebih tinggi Kurangnya minat beli menunjukkan kekurangsukaan calon konsumen pada produk yang ditawarkan.

Kepercayaan menjadi salah satu pondasi terjadinya transaki (Yousafzai, S. Y., Pallister, J. G., dan Foxall, G. R. 2003) sehingga kepercayaan menjadi penting dalam menumbuhkan minat beli konsumen. Tanpa kepercayaan, konsumen tidak akan tertarik untuk membeli produk. Kepercayaan yang tinggi mendorong konsumen untuk 
memiliki komitmen terhadap produk perusahaan (Mulyanto, 2010, 2012) yang mengindikasikan adanya minat terhadap produk. Adanya minat muncul dari diperolehnya kepercayaan, dapat mendorong loyalitas konsumen (Reonald; 2016; Kamilullah, Kusyanti dan Aryadita, 2017).

Begitu pentingnya kepercayaan maka muncul berbagai penelitian yang mengangkatnya menjadi tema penelitian (Dick, Chakravarty dan Bieha, 1990; Dharma, 2006; Rafiq dan Kurniawan, 2009; Mulyanto, 2012; Pramana dan Rastini, 2016; Novel Reonald. 2016; Thixman \& Tileng; 2016). Kepercayaan menjadi faktor yang dapat digunakan untuk mempengaruhi keputusan konsumen (Suryawardana \& Yani, 2015), minat beli secara langsung (F.Tilaar., S.L.H.V.J.Lapian., \& F.Roring., 2018) dan tidak langsung melalui persepsi risiko (Rachmawati, Wahyudi, \& A.P., 2016).

Kepercayaan itu sendiri dapat terwujud karena adanya upaya yang dilakukan oleh pemasar. Kepercayaan dapat muncul karena adanya kualitas layanan (Mulyanto, 2012; Pramana dan Rastini, 2016); citra merek (Ambarwati et al., 2015); iklan (Burhanudin, 2017); reputasi (Wulandari \& Rasipan, 2017). Masalahnya layanan, citra merek, iklan, dan reputasi UMKM produk makanan belum dapat dijalankan dengan baik.

Reputasi memiliki peran penting bagi UMKM makanan di Cileungsi tetapi sejauh ini masih kurang. Disatu sisi reputasi merupakan pendorong kepercayaan (Dick, Chakravarty dan Bieha, 1990). Dharma (2006), mengungkapkan bahwa reputasi berpengaruh terhadap kepercayaan pengguna internet dalam sistem ecommerce di Indonesia. Rafiq dan Kurniawan (2009) mendapatkan temuan yang sama dimana reputasi dapat membangun kepercayaan masyarakat. Hal yang sama terdapat pada penelitian penelitian yang dilakukan oleh Reonald (2016) dan Thixman dan Tileng (2016).

Selain mendorong kepercayaan konsumen (Wulandari \& Rasipan, 2017), reputasi dapat mendorong minat beli konsumen (Shahnaz \& Wahyono, 2016). Hal ini mengindikasikan bahwa reputasi menjadi factor yang dapat mempengaruhi minat beli baik secara langsung maupun tidak langsung melalui kepercayaan.

Ada berbagai perbedaan temuan penelitian dimana minat beli dipengaruhi oleh citra merek (Ambarwati et al., 2015). Pada penelitian ini reputasi mempengaruhi kepercayaan dan minat beli tetapi pada penelitian lainnya resputasi dan kepercayaan memiliki kedudukan setara dalam mempengaruhi minat beli (Shahnaz \& Wahyono, 2016). Dalam penelitian ini kepercayaan dan resputasi mempengaruhi minat beli tetapi penelitian sebelumnya kepercayaan mempengaruhi loyalitas konsumen (Setiawan dan Ukudi, 2007) dan reputasi mempengaruhi Loyalitas Konsumen (Kamilullah, Kusyanti, Aryadita, 2016), reputasi mempengaruhi variabel lain yaitu kepuasan pasien (Aryska, 2017).

Adanya perbedaan temuan dalam berbagai penelitian membuktikan perlunya penelitian tentang reputasi dalam mempengaruhi kepercayaan dan minat beli. Selain itu, permasalahan ini terjadi di UMKM makanan di Cileungsi yang perlu dicari pemecahannya. Reputasi mempengaruhi minat beli secara langsung dan tidak langsung melalui kepercayaan.

\section{TUJUAN PENELITIAN}

Penelitian ini bertujuan untuk menganalisis reputasi dalam mendorong kepercayaan dan minat beli konsumen produk makanan UMKM di Cileungsi.

\section{TELAAH LITERATUR DAN PENGEMBANGAN HIPOTESIS Reputasi}

Reputasi adalah pandangan atau persepsi penilaian konsumen atau pihak lain atas orang, perusahaan atau obyek tertentu. Reputasi juga dapat diartiken sebagai keseluruhan nilai kualitas atau karakter yang terlihat (Audun J., 2007). Dalam kaitannya dengan produsen, reputasi adalah tingkat kepercayaan konsumen atas kejujuran dan kepedulian perusahaan kepada pelanggannya (Javenpaa, 2000. 
Reputasi dapat diukur dengan indikator sebagai berikut (Miles, Morgan P \& Jeffrey G. Covin, 2000):

1. Kompetensi,

2. Kredibilitas dan

3. Nama baik perusahaan.

Reputasi memerlukan waktu yang lama untuk dapat dinilai dan mendapat pengakuan dari khalayak. Karena memerlukan waktu yang lama, maka reputasi yang sudah dimiliki perusahaan harus dijaga agar dapat bertahan dan sustainable dengan jalan menjaga konsistensi antara janji dan pelaksanaannya (Basya, dalam Basya dan Sati, 2006).

\section{Kepercayaan}

Kepercayaan adalah keinginan untuk menggantungkan diri terhadap mitra yang dipercaya (Moorman, Deshpande dan Zaltman, 1993: 82). Kepercayaan adalah kesediaan masingmasing pihak bertindak sesuai yang disepakati bersama (O'Malley and Tynan, 1997). Kepercayaan juga merupakan bentuk kesediaan konsumen untuk menggantungkan diri kepada penjual (Jarvenpaa \& Tractinsky, 2000).

Kepercayaan dapat dikelompookan menjadi tiga (Doh \& Zolnik, 2011), yaitu:

1. Competency trust, yaitu harapan bahwa pihak lain memiliki skil, kompetensi, dan karakteristik tertentu;

2. Contractual trust, pemenuhan janji atas kesepakatan dalam bentuk kontrak baik tertulis maupun tidak tertulis; dan

3. Goodwill trust, keyakinan adanya kepedulian pihak tertentu untuk melakukan respon.

Kepercayaan dapat dilihat dengan indikator (Moorman, Deshpande dan Zaltman, 1993) :

a) Sesuai arapan dan standar.

b) Mampu memberikan pekerjaan yang benar/tidak menyalahi.

c) Pelayanannya konsisten.

d) Bertahan lama (kontinyu).

\section{Minat Beli}

Minat beli dapat dipahami atau diterjemahkan sebagai berikut (Setiawan dan Ihwan, 2004: 29):
1. Kemauan untuk membeli,

2. Keinginan seseorang dalam membeli,

3. Perilaku pembelian secara terus menerus.

Minat beli adalah sikap senang dan berusaha untuk mendapatkan sesuatu pembayaran dengan uang atau pengorbanan (Schiffman dan Kanuk, 2006: 206). Minat beli konsumen adalah tahapan konsumen dalam membentuk pilihan dari serangkaian merek atau produk yang ada.

Dimensi atau indikator minat beli meliputi (Simamora, 2002):

- Minat transaksional yaitu kecenderungan konsumen membeli produk.

- Minat referensial yaitu kesediaan konsumen merekomendasikan produk kepada orang lain.

- Minat preferensial yaitu perilaku seseorang yang memiliki preferensi utama pada produk tersebut.

- Minat eksploratif yaitu keinginan konsumen untuk senantiasa mencari informasi produk yang diminatinya.

\section{Reputasi dan Kepercayaan}

Reputasi sebagai bentuk nilai yang diberikan kepada sebuah obyek memberikan keyakinan kepada pihak lain untuk mempercayai obyek tersebut. Keyakinan yang tinggi terhadap nilai orang atau organisasi akan mendorong timbulkan kepercayaan kepada orang atau organisasi tersebut meskipun belum pernah berinteraksi atau mengenal sebelumnya (McKnight et al., 1998).

Reputasi perusahaan mempengaruhi kepercayaan. Reputasi perusahaan secara langsung membentuk kepercayaan pelanggan terhadap produk atau jasa (Dick, Chakravarty dan Biehal, 1990). Reputasi berpengaruh terhadap kepercayaan pengguna internet dalam sistem e-commerce di Indonesia (Dharma, 2006). Reputasi mempengaruhi kepercayaan konsumen jasa persewaan kendaraan (Novel Reonald, 2016); mempengaruhi kepercayaan masyarakat dalam bertransaksi menggunakan emoney di Indonesia (Thixman \& Tileng, 2016). 
UMKM makanan yang memiliki reputasi dimata konsumen akan mendapat kepercayaan konsumen. Sebaliknya, ketika UMKM tidak mampu dipandang sebagai penyedia makanan yang unggul maka konsumen tidak memiliki kepercayaan terhadap UMKM. Semakin tinggi reputasi UMKM makanan maka semakin tinggi pula kepercayaan konsumen.

H1: reputasi berpengaruh terhadap kepercayaan konsumen.

\section{Kepercayaan dan Minat Beli}

Kepercayaan yang diartikan sebagai kesediaan untuk menggantungkan diri kepada pihak lain menunjukkan keterikatan dengan pihak yang dipercaya. Orang yang percaya terhadap sesuatu akan tertarik dan berupaya untuk mencari informasi. Ketika informasi sudah diperoleh maka tahap berikutnya adalah keinginan untuk mendapatkannya atau berminat terhadap sesuai yang menarik hatinya.

Beberapa penelitian menunjukkan bahwa kepercayaan akan mendorong minat beli. Kepercayaan mempengaruhi minat beli konsumen pada Transaksi Jual Beli Online Melalui Media Sosial (Rachmawati et al., 2016). Kepercayaan mempengaruhi minat beli konsumen toko online (Shahnaz \& Wahyono, 2016). Kepercayaan mempengaruhi minat beli pengguna Shoppee (F.Tilaar. et al., 2018).

Konsumen yang percaya dengan produk ataupun layanan yang diberikan oleh UMKM makanan akan tertarik untuk membeli produk yang dibuat oleh UMKM. Semakin tinggi kepercayaan konsumen kepada UMKM makanan maka makin tinggi pula minat konsumen untuk membeli produk yang ditawarkan.

H2: kepercayaan berpengaruh terhadap minat beli konsumen.

\section{Reputasi dan Minat Beli}

Reputasi atau bisa diartikan sebagai image atau nama baik yang dimiliki oleh pelaku usaha akan mendorong pihak lain untuk tertarik pada produk yang dibuat dan ditawarkan. Konsumen yang memandang produksen memiliki nama baik akan tertarik untuk mendapatkan produk dari perusahaan tersebut.
Beberapa penelitian menunjukkan bahwa reputasi akan mendorong minat beli. Reputasi yang dalam hal ini dimaknai dengan citra merek mempengaruhi minat beli pasta gigi (Ambarwati et al., 2015); Indosat Oredoo (Maghfiroh et al., 2016); keripik singkong (Raharjo \& Mulyanto, 2018). Reputasi juga dapat mempengaruhi tidak hanya minat beli tetapi sampai kepada keputusan pembelian (Suryawardana \& Yani, 2015).

UMKM makanan yang memiliki reputasi atau image atau nama baik di mata konsumen akan menarik konsumen untuk membeli produk makanan yang dihasilkan dan ditawarkan. Semakin tinggi reputasi disematkan kepada UMKM makanan maka makin tinggi pula minat konsumen untuk membeli produk yang ditawarkan.

H3: reputasi berpengaruh terhadap minat beli konsumen.

Berdasarkan uraian pada hubungan antar variabel dan hipotesis yang diajukan maka model penelitian dapat digambarkan sebagai berikut:

Gambar 1

Model Penelitian

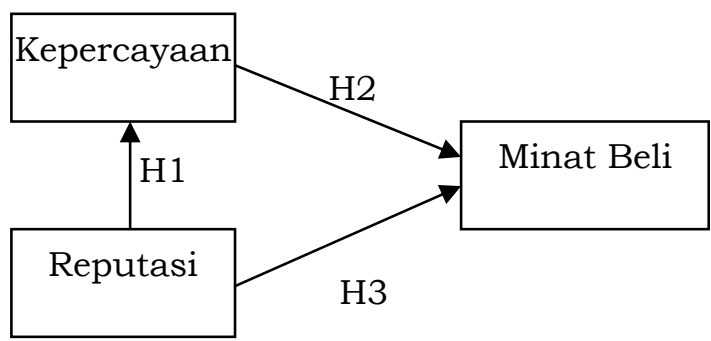

Sumber: Pengembangan Konsep, 2017

\section{METODE PENELITIAN Sampel Penelitian}

Penelitian dilakukan dengan dengan menyebarkan kuesioner kepada 100 konsumen makanan di Cileungsi, Bogor, Jawa Barat. Metode sampling yang digunakan adalah accidental sampling yaitu dengan menyebarkan kuesioner kepada konsumen yang membeli produk makanan dari UMKM (warung) yang ada di Cileungsi. 


\section{Desain Penelitian}

Penelitian menggunakan pendekatan kuantitatif yaitu explanatory research yaitu dengan menguji pengaruh antar variabel (Hair, et al, 1998). Pengaruh antar variabel yang diuji adalah model structural pengaruh reputasi terhadap kepercayaan, kepercayaan terhadap minat beli dan reputasi terhadap minat beli.

\section{Operasionalisasi Variabel}

Operasionalisasi variable penelitian adalah sebagai berikut:

Tabel 1

Operasionalisasi Variabel

\begin{tabular}{|c|c|c|}
\hline Variabel/ Konsep & Indikator & Skala \\
\hline $\begin{array}{c}\text { Reputasi }\left(\xi_{1}\right) \text {, adalah } \\
\text { keseluruhan kualitas } \\
\text { atau karakter yang } \\
\text { terlihat dan dinilai } \\
\text { oleh individu (Audun } \\
\text { J., 2007) } \\
\end{array}$ & $\begin{array}{l}\text { Kompetensi } \\
\text { Kredibilitas } \\
\text { Nama baik }\end{array}$ & $\begin{array}{l}\text { Interval } \\
1-10\end{array}$ \\
\hline \begin{tabular}{|c|} 
Kepercayaan $\left(\eta_{1}\right)$ \\
adalah kesediaan \\
menggantungkan diri \\
terhadap mitra \\
(Moorman, \\
Deshpande dan \\
Zaltman, 1993: 82 ) \\
\end{tabular} & $\begin{array}{l}\text { Kesesuaian } \\
\text { Baik } \\
\text { Konsisten } \\
\text { Sustain }\end{array}$ & $\begin{array}{l}\text { Interval } \\
1-10\end{array}$ \\
\hline \begin{tabular}{|c|} 
Minat Beli $\left(\eta_{2}\right)$ adalah \\
sikap individu yang \\
mempunyai kekuatan \\
atau dorongan \\
untuk mendekati \\
atau mendapatkan \\
objek tertentu \\
(Simamora, \\
$2002: 131)$. \\
\end{tabular} & $\begin{array}{l}\text { Transaksi- } \\
\text { onal } \\
\text { Referensial } \\
\text { Preferensial } \\
\text { Eksploratif }\end{array}$ & $\begin{array}{l}\text { Interval } \\
1-10\end{array}$ \\
\hline
\end{tabular}

\section{Metode Analisis}

Penelitian menggunakan pendekatan kuantitatif berupa model persamaan structural atau Structural Equation Modeling (SEM). Dengan analisis ini maka pengaruh anatar variable diuji secara bersamaan sebagai sebuah model utuh. Alat analisis yang digunakan adalah AMOS Versi 23.

Tahapan analisis diawali dengan pengujian instrument atau uji validitas dan reliabilitas yaitu menggunakan confirmatory factor analysis (CFA). Validitas terpenuhi jika nilai p. muatan faktor (loading factors) lebih kecil dari nilai kritis (Sig. $<\alpha$ ) dan muatan faktor standarnya (standardized loading factors) lebih besar 0.5 (SLF > 0.50). Reliabilitas terpenuhi jika nilai composite reliability $(\mathrm{CR})>0.70$ dan variance extracted $(\mathrm{VE})>$ 0.50 .

Tahapan analisis berikutnya adalah analisis dekstriptif yaitu mendiskripsikan kategori variable dan indikatornya. Kemudian analisis dilajutkan dengan uji model (Goodness of Fit). Pengujian dilakukan dengan perbandingan hasil analisi terhadap persyaratan analisisnya yang terdiri dari Chi-square, Goodness-of-Fit Index (GFI), The Root Mean Square Error of Approximation (RMSEA), Relative Fit Index (RFI).

Analisis berikutnya adalah pengujian hipotesis. Pengujian hipotesis dilakukan dengan melihat nilai koefisien antar variable laten dan probabilitasnya. Hipotesis terpenuhi apabila nilai probabilitas lebih kecil daripada taraf uji penelitian $(\operatorname{Sig}<\alpha)$.

\section{HASIL PENELITIAN DAN PEMBAHASAN Hasil Penelitian Model Hasil Analisis Pengujian Instrumen}

Hasil analisis pengujian instrument adalah sebagai berikut: Gambar 2 Model Uji Instrumen

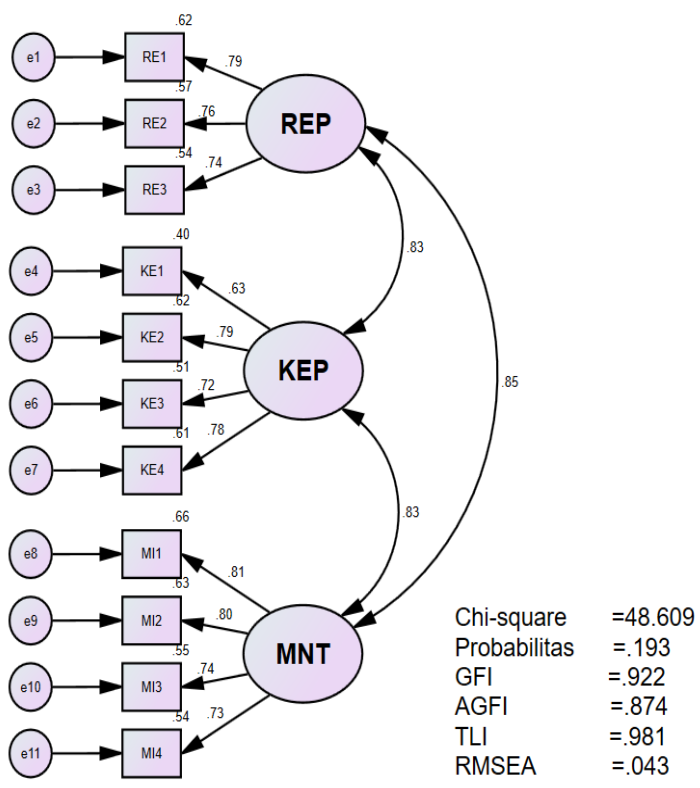

Sumber: Data diolah, 2018 
Dari gambar di atas, model untuk uji instrumen sudah dapat dikatakan layak karena memiliki nilai Chi-Square yang rendah, probabilitas lebih besar dari 0,5; GFI lebih besar dari 0,9 dan RMSEA yang relative kecil yaitu kurang dari 0,08.

Pengujian instrument selanjutnya dirangkum pada table berikut:

Tabel 2

Uji Instrumen

\begin{tabular}{|c|l|c|c|c|c|c|}
\hline Kode & Variabel/Indikator & $\begin{array}{c}\text { SLF } \\
>0.5\end{array}$ & Error & $\begin{array}{c}\text { CR } \\
>0.7\end{array}$ & $\begin{array}{c}\text { VE } \\
>0.5\end{array}$ & Keputusan \\
\hline REP & REPUTASI & & & 0.81 & 0.58 & Reliabel \\
RP1 & Kompetensi & 0.79 & 0.38 & & & Valid \\
RP2 & Kredibilitas & 0.76 & 0.42 & & & Valid \\
RP3 & Nama Baik & 0.74 & 0.45 & & & Valid \\
\hline KEP & KEPERCAYAAN & & & 0.82 & 0.54 & Reliabel \\
KE1 & Kesesuaian & 0.64 & 0.59 & & & Valid \\
KE2 & Baik & 0.78 & 0.39 & & & Valid \\
KE3 & Konsisten & 0.73 & 0.47 & & & Valid \\
KE4 & Sustainable & 0.78 & 0.39 & & & Valid \\
\hline MNT & MINAT & & & 0.85 & 0.59 & Reliabel \\
MI1 & Transaksional & 0.81 & 0.34 & & & Valid \\
MI2 & Referensial & 0.79 & 0.38 & & & Valid \\
MI3 & Preferensial & 0.74 & 0.45 & & & Valid \\
MI4 & Eksploratif & 0.73 & 0.47 & & & Valid \\
\hline
\end{tabular}

Sumber: Data diolah, 2018

Instrumen pengukur dan variable yang diukur seluruhnya valid dan reliabel.

- Reputasi: memiliki tiga indikator yang seluruhnya valid karena nilai SLF untuk masing-masing indikator $\geq 0,5$; dan telah reliabel karena CR $0,81 \geq 0,7$ dan $\mathrm{VE} 0,58 \geq 0,5$.dan reiabel.

- Kepercayaan: memiliki empat indikator yang seluruhnya valid karena nilai SLF untuk masingmasing indikator $\geq 0,5$; dan telah reliabel karena CR $0,82 \geq 0,7$ dan VE $0,54 \geq 0,5$.dan reiabel.

- $\quad$ Minat beli: memiliki empat indikator yang seluruhnya valid karena nilai SLF untuk masing-masing indikator $\geq 0,5$; dan telah reliabel karena $\mathrm{CR}$ $0,85 \geq 0,7$ dan $\mathrm{VE} 0,59 \geq 0,5$.dan reiabel.

\section{Deskripsi Variabel}

Kategori penilaian untuk masingmasing variable dan indikatornya adalah sebagai berikut:

Tabel 3

Deskripsi

\begin{tabular}{|c|l|c|c|}
\hline Kode & Variabel/Indikator & Nilai & Kategori \\
\hline REP & REPUTASI & 7.76 & Tinggi \\
RP1 & Kompetensi & 7.73 & Tinggi \\
RP2 & Kredibilitas & 7.69 & Tinggi \\
RP3 & Nama Baik & 7.87 & Tinggi \\
\hline KEP & KEPERCAYAAN & 7.85 & Tinggi \\
KE1 & Kesesuaian & 7.89 & Tinggi \\
KE2 & Baik & 7.79 & Tinggi \\
KE3 & Konsisten & 7.86 & Tinggi \\
KE4 & Sustainable & 7.85 & Tinggi \\
\hline MNT & MINAT & 7.85 & Tinggi \\
MI1 & Transaksional & 7.56 & Tinggi \\
MI2 & Referensial & 8.16 & Tinggi \\
MI3 & Preferensial & 7.86 & Tinggi \\
MI4 & Eksploratif & 7.80 & Tinggi \\
\hline
\end{tabular}

Sumber: Data dan diolah, 2018

Dari data di atas, dapat dijelaskan sebagai berikut:

- Reputasi UMKM secara umum dalam kategori tinggi dimana berturutturut indikatornya adalah nama baik, kompetensi dan kredibilitas.

- Kepercayaan konsumen pada UMKM secara umum tinggi dimana berturut-turut kepercayaan pada kesesuaian, konsitensi, sustainability an kebaikan.

- Minat beli konsumen pada produk UMKM secara umum tinggi dengan urutan minat referensial, preferensial, eksploratif dan transaksional.

\section{Model Hasil Analisis}

Model hasil analisis secara umum berupa gambar dan text output. Hasil analisis menunjukkan pengaruh antar variable laten dan variable laten dengan pembentuknya. Berdasar hasil analisis dapat dilakukan pengujian model structural dan pengujian hipotesis. Hasil analisis structural disajikan pada gambar berikut: 
Gambar 3

Model Hasil Analisis

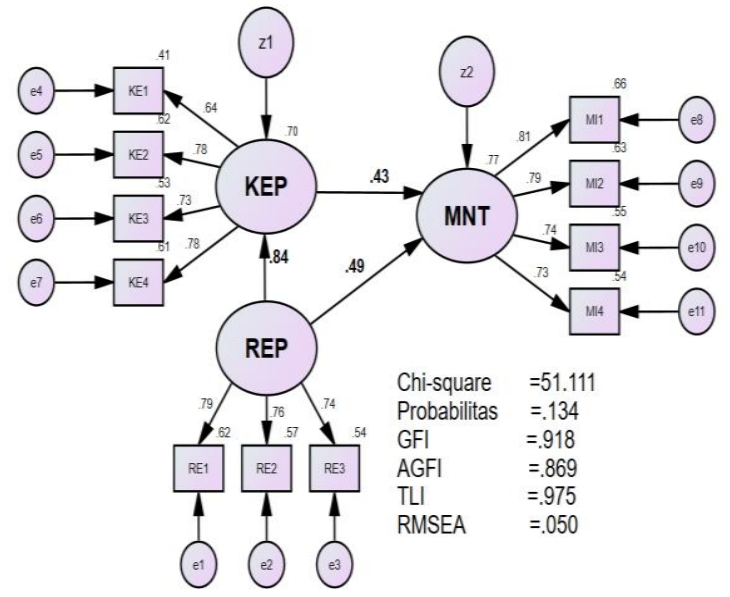

Sumber: Data diolah, 2018

\section{Uji Model Struktural}

Uji model struktural disajikan pada tabel berikut:

Tabel 4

Uji Model Struktural

\begin{tabular}{|c|c|c|c|}
\hline Ukuran & Persvaratan & Esstimasi & Kategori \\
\hline Absolut & & & \\
Chi-Square & Kecil & 51,111 & Fit \\
$P$ & $\geq 0,05$ & 0,134 & Fit \\
RMSEA & $\leq 0,08$ & 0,050 & Fit \\
P (close fit) & $\geq 0,05$ & 0,473 & Fit \\
GFI & $\geq 0,90$ & 0,918 & Fit \\
\hline Inkremental & & & \\
NFI & $\geq 0,90$ & 0,915 & Fit \\
CFI & $\geq 0,90$ & 0,982 & Fit \\
IFI & $\geq 0,90$ & 0,982 & Fit \\
TLI & $\geq 0,90$ & 0,975 & Fit \\
RFI & $\geq 0,90$ & 0,887 & Marginal \\
AGFI & $\geq 0,90$ & 0,869 & Marginal \\
\hline
\end{tabular}

Sumber: Data diolah, 2018

model struktural menunjukkan goodness of fit test yang berarti bahwa model yang dianalisis merupakan model yang baik sehingga layak digunakan untuk menjelaskan pengaruh antar varaiabel. Terpenuhinya kelayakan model tidak terlepas dari hasil analisi dimana indicator seperti Chi-Square, $\mathrm{p}$, RMSEA, $p$ (close fit), GFI, NFI, CFI, IFI, dan TLI dengan kategori fit. Dari sekiat indicator pengujian hanya RFI dan AGFI yang tidak fit tetapi masih dalam kategori marginal fit.

\section{Pengujian Hipotesis}

Hasil pengujian hipotesis pada penelitin ini dirangkum pada tabel berikut:

Tabel 5

Pengujian Hipotesis

\begin{tabular}{|c|c|c|c|}
\hline Hipotesis & $\begin{array}{c}\text { Koefisien } \\
\text { (Std) }\end{array}$ & p-value & Keputusan \\
\hline H1: Reputasi $\rightarrow$ Kepercayaan & 0,839 & tik & Siginifikan \\
\hline H2: Kepercayaan $\rightarrow$ Minat Beli & 0,429 & 0,042 & Siginifikan \\
\hline H3: Reputasi $\rightarrow$ Minat Beli & 0,489 & 0,021 & Signifikan \\
\hline
\end{tabular}

Sumber: Hasil analisis, 2018

Tiga hipotesis yang diajukan seluruhnya signifikan. Hal ini menunjukkan bahwa reputasi berpengaruh terhadap kepercayaan, kepercayaan berpengaruh terhadap minat beli dan reputasi berpengaruh terhadap minat beli.

\section{Pembahasan \\ Reputasi dan Kepercayaan}

Reputasi memiliki pengaruh terhadap kepercayaan dengan arah positif sebesar 0,839. Semakin tinggi reputasi UMKM dimata konsumen maka semakin tinggi pula kepercayaan konsumen kepada UMKM. Reputasi UMKM sebagai penyedia makanan bagi konsumen yang memiliki nama baik, kompetensi dan kredibilitas membuat kepercayaan konsumen semakin tinggi dimana konsumen percaya bahwa UMKM makanan di Cileungsi mampu menyediakan yang dibutuhkan konsumen.

Hasil penelitian ini mendukung beberapa penelitian sebelumnya dimana reputasi perusahaan mempengaruhi kepercayaan. Makin tinggi reputasi perusahaan maka makin tinggi kepercayaan pelanggan kepada produk atau jasa (Dick, Chakravarty dan Biehal, 
1990). Reputasi mempengaruhi kepercayaan pengguna internet dalam sistem e-commerce di Indonesia (Dharma, 2006); jasa persewaan kendaraan (Novel Reonald, 2016); bertransaksi menggunakan e-money di Indonesia (Thixman \& Tileng, 2016).

\section{Kepercayaan dan Minat Beli}

Kepercayaan memiliki pengaruh terhadap minat beli dengan arah positif sebesar 0,429. Semakin tinggi kepercayaan konsumen kepada UMKM makanan maka semakin tinggi pula minat beli konsumen produk makanan yang dihasilkan/ditawarkan UMKM. Kepercayaan khususnya berkaitan dengan kesesuaian produk makanan yang ditawarkan dengan yang diharapkan mendorong minat konsumen khususnya minat referensional atau merekomendasikan produk makanan UMKM kepada pihak lain atau konsumen lain.

Hasil penelitian ini mendukung beberapa penelitian sebelumnya dimana kepercayaan mempengaruhi minat beli Transaksi Jual Beli Online Melalui Media Sosial (Rachmawati et al., 2016). Kepercayaan mempengaruhi minat beli konsumen toko online (Shahnaz \& Wahyono, 2016). Kepercayaan mempengaruhi minat beli pengguna Shoppee (F.Tilaar. et al., 2018). Kepercayaan pada UMKM makanan mempengaruhi minat beli konsumen. Makin tinggi kepercayaan dipersepsikan oleh konsumen maka makin tinggi minat beli konsumen akan produk yang ditawarkan oleh UMKM.

\section{Reputasi dan Minat Beli}

Reputasi memiliki pengaruh terhadap minat beli dengan arah positif sebesar 0,489. Semakin tinggi reputasi UMKM makanan maka semakin tinggi pula minat beli konsumen produk makanan yang dihasilkan/ditawarkan UMKM. Reputasi khususnya berkaitan dengan nama baik sebagai UMKM penyedia makanan mendorong minat konsumen khususnya minat referensional atau merekomendasikan produk makanan UMKM kepada pihak lain atau konsumen lain.
Hasil penelitian ini mendukung beberapa penelitian sebelumnya dimana reputasi mempengaruhi minat beli pasta gigi (Ambarwati et al., 2015); Indosat Oredoo (Maghfiroh et al., 2016); keripik singkong (Raharjo \& Mulyanto, 2018). Reputasi UMKM makanan mempengaruhi minat beli konsumen. Makin tinggi reputasi dipersepsikan oleh konsumen maka makin tinggi minat beli konsumen akan produk yang ditawarkan oleh UMKM.

\section{KESIMPULAN \\ Simpulan}

Reputasi mempengaruhi minat beli konsumen produk makanan UMKM secara langsung maupun tidak langsung melalui kepercayaan yaitu reputasi meningkatkan kepercayaan dan mendorong minat beli konsumen:

- Reputasi berpengaruh terhadap kepercayaan dengan arah positif..

- Kepercayaan berpengaruh terhadap minat beli konsumen UMKM makanan dengan arah positif

- Reputasi berpengaruh terhadap minat beli konsumen UMKM makanan dengan arah positif.

\section{Saran}

Berdasarkan penelitian ini, penulis memberikan saran atau masukan sebagai berikut:

- UMKM produk makanan hendaknya berupaya untuk menjaga reputasi yaitu nama baik dan meningkatkan reputasi yaitu kompetensi dan kredibilitasnya.

- UMKM produk makanan hendaknya menjaga kepercayaan yang telah diberikan konsumen dengan menjaga kesesuaian produk yang ditawarkan.

- Perlu penelitian lanjutan dengan menguji kembali dan mengeksplorasi variable penelitian secara mendalam.

\section{DAFTAR PUSTAKA}

Ambarwati, M., Sunarti, \& Mawardi, M. K. (2015). Pengaruh Citra Merek Terhadap Minat Beli (Survei Pada Mahasiswa Universitas Brawijaya 
Yang Menggunakan Pasta Gigi Pepsodent). Jurnal Administrasi Bisnis (JAB), 25(1), 7.

Burhanudin, R. (2017). Pengaruh Iklan Traveloka di Televisi Terhadap Minat Beli Konsmen (Studi di Indonesia). e-Proceeding of Management, 4(2), 7.

Dama, D. (2016). Analisis Faktor-Faktor yang Mempengaruhi Minat Beli Konsumen dalam Memilih Laptop Acer di Toko Lestari Komputer Manado. Jurnal Berkala Ilmiah Efisiensi, 16(01), 12.

Dharma, Fitra. 2006. Pengaruh Structural Assurance dan Perceived Terhadap Trust Pengguna Internet di Sistem E-Commerce. Simposium Nasional Akuntansi 9. (F.Tilaar. et al.), Padang.

Doh, S., \& Zolnik, E. J. (2011). Social Capital and Entrepreneurship: An Exploratory Analysis. African Journal of Business Management, Vol. 5, No. 12, 4961-4975.

F. Tilaar., S.L.H.V.J.Lapian., \& F.Roring. (2018). Pengaruh Kepercayaan dan Motivasi Terhadap Minat Beli Pengguna Shoppe secara Online pada Anggota Pemuda GMIM Zaitun Mahakeret. Jurnal EMBA, 6(4), 10.

Heru Mulyanto 2012. Kepuasan dan Kepercayaan dalam Mempengaruhi Komitmen Peritel Mebel di Jabodetabek. Jurnal Pengembangan Wiraswasta Vol. 14 No. 2 - Agustus 2012. LP2M STIE IPWIJA: 143-156.

I Gede Yogi Pramana dan Ni Made Rastini. 2016. Pengaruh Kualitas Pelayanan Terhadap Kepercayaan Nasabah dan Loyalitas Nasabah Bank Mandiri Cabang Veteran Denpasar Bali. E-Jurnal Manajemen Unud, Vol. 5, No.1, 2016: 706-733.

Jarvenpaa, Sirka. L et al. 2000. Consumer Trust in an Internet Store. Information Technology and Management 1. (F.Tilaar. et al.); pp 45-71.

Jihad Kamilullah, Ari Kusyanti, Himawat Aryadita. 2016. Analisis Pengaruh
Kepercayaan, Kepuasan, dan Reputasi Terhadap Loyalitas Konsumen Online Shop Dalam Pembelian Produk di Toko XYZ; Jurnal Pengembangan Teknologi Informasi dan Ilmu Komputer eISSN: 2548-964X; Vol. 2, No. 7, Juli 2016, hlm. 2660-2669.

Josang, Audun. 2007. Trust and Reputation system. Foundations of Security Analysis and Design IV. (F.Tilaar. et al.), Australia.

Maghfiroh, A. a., Arifin, Z., \& Sunarti. (2016). Pengaruh Citra Merek Terhadap Minat Beli dan Keputusan Pembelian (Survei pada Mahasiswa Program Studi Administrasi Binis Tahun Angkatan 2013/2014 Fakultas Ilmu Administrasi Universitas Brawijaya Malang Pembeli Indosat Ooredoo). Jurnal Administrasi Bisnis (JAB) |, 40(1), 9.

Marsyel Thixman dan Kartika Gianina Tileng. 2016. Analisis Pengaruh Usability, Reputasi dan Keamanan Terhadap Kepercayaan Masyarakat dalam Bertransaksi Menggunakan E-Money di Indonesia. Jurnal Teknologi Informasi-Aiti, Vol. 14. No.1, Februari 2016: 1 - 103).

Meilani, Y. F. C. P., \& Simanjuntak, S. (2012). Faktor yang Mempengaruhi Minat Beli Produk Makanan dan Minuman Usaha Kecil Menengah Kabupaten Tangerang. Jurnal Manajemen dan Kewirausahaan, 14(2), 9.

Metha Aryska. 2017. Pengaruh Reputasi Perusahaan dan Kualitas Pelayanan Terhadap Kepuasan Pasien (Kasus Rumah Sakit Islam Ibnu Sina Pekanbaru). JOM FISIP Vol. 4 No. 1 - Februari 2017 Page 1.

Miles, Morgan P \& Jeffrey G. Covin, 2000, "Environmental Marketing: A Source of Reputational, Competitive and Financial Advantage", Journal of Business Ethics.

Moorman, Christin, Gerald Zaltman and Rohit Deshpande (1993) Relationships Between Provider and Users of Market Reseat: The Dinamics of Trust Within and 
Between Organzsations, Journal Marketing Research, Vol XXXIX, 314-28.

Muhammad Rafiq dan Bayu Tri Kurniawan. 2009. Pengaruh Reputasi Dalam Membangun Kepercayaan Masyarakat Terhadap Rumah Sakit Umum Pringsewu; JMK Vol. 7 No. 4, September 2009: 129-138.

Mulyo Budi Setiawan dan Ukudi. 2007, Pengaruh Kualitas Layanan, Kepercayaan dan Komitmen Terhadap Loyalitas Nasabah (Studi pada PD BPR Bank Pasar Kendal. Jurnal Bisnis dan Ekonomi (JBE) September 2007, Hal. 215-227 ISSN: 1412-3126 Vol. 14, No.2.

Novel Reonald. 2016. Pengaruh Reputasi Perusahaan Rental dan Relationship Value Terhadap Kepercayaan dan Komitmen serta Loyalitas Perusahaan Pengguna Jasa Persewaan Kendaraan di Kalimantan Timur. Jurnal Ekonomika Vol 5, No 2: (Manajemen, Akuntansi, dan Perbankan Syari'ah)-EKONOMIUWGM: 90-104.

Rachmawati, R. M., Wahyudi, H. D., \& A.P., A. H. (2016). Pengaruh Kepercayaan Terhadap Minat Beli Melalui Persepsi Risiko Pada Transaksi Jual Beli Online Melalui Media Sosial (Rachmawati et al.). Jurnal Ekonomi Bisnis, 21 ("<Produk, Iklan, Sikap, Minat.pdf>,"), 11.
Raharjo, R. M., \& Mulyanto, H. (2018). Kualitas Produk, Citra Merek dan Minat Beli Konsumen Keripik Singkong. Jurnal Manajemen Kewirausahaan, 15(1), 12.

Shahnaz, N. B. F., \& Wahyono. (2016). Faktor yang Mempengaruhi Minat Beli Konsumen di Toko Online. Management Analysis Journal, 11.

Simamora., B, 2002. Panduan Riset Perilaku Konsumen, Pustaka Utama, Surabaya.

Suryawardana, E., \& Yani, T. E. (2015). Analisis Pengaruh Reputasi, Kualitas Pelayanan dan Kepercayaan Terhadap Keputusan Pembelian pada Stasiun Pengisian Bahan Bakar Umum (SPBU) Di kota semarang. J. DINAMIKA SOSBUD, $17(2), 12$.

Wulandari, A., \& Rasipan. (2017). Peran Reputasi dalam Mendorong Kepercayaan Konsumen. Jurnal Manajemen Kewirausahaan, 14(2), 12.

Yousafzai, S. Y., Pallister, J. G., dan Foxall, G. R. 2003. A Proposed Model of Trust for Electronic Banking, Technovation.

Yuniyanto, H. R., \& Sirine, H. (2018). Pengaruh Iklan terhadap Minat Beli Pengguna Youtube dengan Brand Recognition sebagai Variabel Intervening. Esensi: Jurnal Bisnis dan Manajemen, 8(1). doi: 10.15408/ess.v8i1.5885. 